\title{
Sportszív vagy strukturális szívizombetegség? Szív mágneses rezonanciás vizsgálat diagnosztikus szerepe sportolóknál strukturális szívbetegség gyanúja esetén
}

\author{
Csécs Ibolya, Czimbalmos Csilla, Tóth Attila, Kiss Orsolya, Komka Zsolt, \\ Bárczi György, Kováts Tímea, Suhai Ferenc Imre, Sydó Nóra, Simor Tamás', \\ Gellér László, Becker Dávid, Merkely Béla, Vágó Hajnalka
}

Semmelweis Egyetem, Városmajori Szív- és Érgyógyászati Klinika, Budapest

${ }^{1}$ Pécsi Tudományegyetem, Klinikai Központ Szívgyógyászati Klinika, Pécs

Levelezési cím: Dr. Vágó Hajnalka, 1122 Budapest, Városmajor u. 68., E-mail: vagoha@gmail.com

\begin{abstract}
A sportolókat érintő halálozás vezető oka az intenzív sporttevékenység során elszenvedett hirtelen szívhalál (HSZH). Célunk volt a szív mágneses rezonanciás (MR) vizsgálat diagnosztikus szerepének tanulmányozása strukturális szívizombetegség gyanúja miatt vizsgált sportolók esetén, a sportolói HSZH etiológiájának tisztázása, valamint a diagnosztizált kórképek gyakoriságának meghatározása.

A Városmajori Szív- és Érgyógyászati Klinikán 2011. január és 2016. december között 153 sportoló (112 férfi, átlagéletkor: $26,5 \pm 10,5$ év) szív MR-vizsgálatát végeztük strukturális szívizombetegség gyanújával, 10 esetben reanimációt követően. Hossz- és rövidtengelyi síkokban mozgó MR-felvételeket készítettünk, meghatároztuk a bal és jobb kamrai volumeneket, izomtömegeket és ejekciós frakciókat, valamint vizsgáltuk a kamrai falmozgászavarok jelenlétét. Akut miokardiális károsodás gyanúja esetén T2-súlyozott felvételeket készítettünk a miokardiális ödéma azonosítására. Az esetleges nekrózis/fibrózis megítélésére az esetek 88\%-ában kontrasztanyag adásával egészítettük ki a vizsgálatot. Az MR-vizsgálat 39 sportoló (25,5\%) (37 férfi, átlagéletkor: 27,2ะ17,0 év) esetén igazolt szívizom-betegséget. Hipertrófiás cardiomyopathiát (HCM) 9 esetben (23,0\%), arrhythmogen jobb kamrai cardiomyopathiát (ARVC) 7 esetben $(18,0 \%)$, két-két esetben dilatatív $(5,0 \%)$, illetve noncompact cardiomyopathiát $(5,0 \%)$ diagnosztizáltunk. Az MR-felvételeken további két esetben $(5,0 \%)$ korábban lezajlott miokardiális infarktus maradványhege ábrázolódott. Tizenöt esetben (38,5\%) noniszkémiás eredetre utaló késői típusú kontraszthalmozás ábrázolódott, az esetek nagy részében falmozgászavar (12 beteg), illetve EKG-eltérés ( 8 beteg) nélkül. Nyolc esetben gócos, subepi-midmiokardiális jellegü kontraszthalmozási mintázat igazolódott, amely leginkább lezajlott myocarditis maradványhegének felelhet meg, közülük három sportolónál volt ismert lezajlott myocarditis. A noniszkémiás kontraszthalmozási mintázatot mutató sportolók közül 7 esetben atípusos halmozási mintázat volt jelen. Az MR-kép egy esetben Fabry-betegségre (3,0\%) volt típusos, további egy esetben pedig koronária eredési anomália ábrázolódott (3,0\%). Ezen belül a fent említett kórképek megoszlása a 10 reanimált beteg esetében a következő volt: három betegnél igazolódott ARVC, két betegnél atípusos halmozást láttunk, a további 5 esetben strukturális eltérést nem azonosítottunk.

Sportolók esetén a szív MR-vizsgálatnak kiemelt diagnosztikai szerepe lehet a nehezen felismerhetö kórképek (pl. csúcsi HCM, ARVC, lezajlott myocarditis) azonosításában. A szív MR-vizsgálat atípusos miokardiális fibrózist igazolhat falmozgászavar, illetve EKG-eltérés hiányában is, ám a háttérben álló kórkép az esetek egy részében részletes kivizsgálást követően sem azonosítható egyértelmüen. A cardiomyopathiák közül az általunk vizsgált csoportban a leggyakoribb kórkép a HCM, míg a HSZH hátterében álló leggyakoribb strukturális eltérés az ARVC volt.
\end{abstract}

Kulcsszavak: sportoló, sportszív, hirtelen szívhalál, szív mágneses rezonancia 


\section{Structural myocardial disease or athlete's heart? The diagnostic role of cardiac magnetic resonance (CMR) imaging in athletes with the suspicion of structural heart disease}

According to literature data sudden cardiac death (SCD) is the most common cause of death in athletes occurring usually during intensive training. Our aim was to investigate the diagnostic role of cardiac magnetic resonance (CMR) in athletes with suspected structural myocardial diseases, to investigate the etiology of SCD, and to determine the frequency of the pathological conditions/diseases.

At the Heart and Vascular Center of the Semmelweis University during a 6-year period (2011-2016) we performed CMR scans on 153 athletes (112 males, age: $26.5 \pm 10.5$ y) with suspected structural myocardial disease. Ten athletes were investigated after aborted SCD. We performed long- and short axis movies, measured the left and right ventricular ejection fractions, volumes and masses, and also investigated the wall motion abnormalities. T2-weighted images were performed for the detection of myocardial edema, and in $88 \%$ of the cases we investigated the necrosis/fibrosis on late gadolinium enhancement (LGE) images.

CMR confirmed the diagnosis of structural myocardial disease in 39 athletes (25.5\%) (37 male, age: 27,2 $\pm 17,0$ y): hypertrophic cardiomyopathy (HCM) in 9 cases (23.0\%), arrhythmogenic right ventricular cardiomyopathy (ARVC) in 7 cases $(18.0 \%)$, noncompaction and dilated cardiomyopathy in 2-2 cases (5-5\%). Subendocardial LGE, suggesting previous myocardial infarction, was found in 2 cases (5.0\%), non-ischaemic LGE pattern in 15 cases (38.5\%; patchy subepi-mid-myocardial LGE in 8 athletes, atypical LGE in 7 cases). One athlete was diagnosed with Fabry-disease (3.0\%), one with coronary artery abnormality (3.0\%). In aborted SCD cases CMR findings were the following: ARVC $(n=3)$, atypical LGE pattern $(n=2)$, and no structural myocardium abnormality $(n=5)$.

In case of athletes CMR can have a key role in the identification of challenging disorders like apical HCM, ARVC, postmyocarditis. CMR can detect fibrosis even in the absence of wall motion and ECG abnormalities. The diagnosis, however, is not clear in some cases despite the thorough investigation. In our study the most common CMP was HCM, and in the SCD group ARVC was the leading CMP.

Keywords: athlete, athlete's heart, sudden cardiac death, cardiac magnetic resonance

\section{Bevezetés}

A sporttevékenység közben váratlanul fellépő, végzetes kimenetelü kardiovaszkuláris esemény, a hirtelen szívhalál $(\mathrm{HSZH})$ ritka, de rettegett kórkép. A HSZH pontos incidenciája nem ismert, nagy esetszámú tanulmányok összegzése alapján gyakoriságát 1-3/100 000re becsülik $(1,2,3)$. A HSZH előfordulását az életkor és a nem erősen befolyásolják. A sportolók HSZH incidenciája a korral emelkedik: 35 év felett a HSZH incidenciája 5-10-szer magasabb, mint fiatalabb életkorban (1, $4,5,6)$. A női sportolók HSZH rizikója 2-25-szer alacsonyabb, mint a férfiaké $(2,5,7)$.

A HSZH esetek hátterében álló kórkép az esemény előtt többnyire nem ismert annak ellenére, hogy jelentős hányadban diagnosztizálható betegség áll a háttérben $(1,6)$. A HSZH sokszor fizikai terhelés alatt vagy után következik be, közvetlen oka legtöbbször kamrai tachycardia, ritkábban kamrafibrilláció. A rendszeres testedzés protektív hatásaival szemben a versenysportolókat ért tartós, extrém fizikai igénybevétel látens patológiás elváltozások esetén káros hatást gyakorolhat a kardiovaszkuláris rendszerre. A HSZH hátterében álló leggyakoribb kórképek az életkorral változnak: fiatal sportolók HSZH eseményei hátterében leggyakrabban noniszkémiás strukturális szívbe- tegség áll, míg 35 év felett az iszkémiás kóreredet gyakoribb $(2,8)$.

A hipertrófiás, illetve arrhythmogen jobb kamrai cardiomyopathia a 35 év alatti sportolók HSZH-nak leggyakoribb okai $(9,10)$, gyakoriságuk földrajzi és etnikai eltérést mutat. A fiziológiás sportszívtől történő elkülönítésük sok esetben nehezített, ez különösen igaz a sportolói normál és kóros tartomány átfedő, az ún. szürke zónába eső sportolókra $(11,12)$. A sportszív vizsgálatában a képalkotó diagnosztikai módszerek fejlődése nagy előrelépést hozott. A szív mágneses rezonanciás (MR) vizsgálat a bal, illetve jobb kamrai volumenek, illetve izomtömeg meghatározásának referenciamódszere, továbbá speciális MR-szekvenciák és kontrasztanyag segítségével szövetspecifikus információt nyújt. Sportolók esetén szív MR-vizsgálat végzése akkor javasolt, ha a rutinszerủen elvégzett fizikális vizsgálat, családi anamnézis, 12 elvezetéses EKG alapján felmerül valamely strukturális szívbetegség gyanúja, és az elvégzett echokardiográfia nem diagnosztikus vagy további kérdést vet fel.

A sportolók körében fellépő HSZH gyakoriságáról és a háttérben meghúzódó pontos okokról jelenleg hivatalos hazai statisztikai adatokkal nem rendelkezünk. Becslések alapján Magyarországon a HSZH incidenciája megegyezik az ismertetett nemzetközi adatokkal (13). 
Célunk volt a szív MR-vizsgálat diagnosztikus szerepének tanulmányozása strukturális szívizombetegség gyanúja miatt vizsgált sportolók esetén, a sportolói hirtelen szívhalál (HSZH) etiológiájának tisztázása, valamint a diagnosztizált kórképek gyakoriságának meghatározása.

\section{Betegek és módszerek}

Klinikánkon 2011. január és 2016. december között 153 kaukázusi rasszhoz tartozó versenysportoló (112 férfi, átlagéletkor: $26,5 \pm 10,5)$ szív mágneses rezonanciás (MR) vizsgálatát végeztük strukturális szívizombetegség gyanúja miatt. A sportolók többsége kevert terhelésű (statikus és dinamikus komponenseket egyaránt tartalmazó) sportághoz tartozott (131 fö, 85,6\%), a sportolók 41,8\%-a (64 fő) válogatott játékos, olimpiai kerettag volt. Tíz sportolót, reanimációt követően, két főt dokumentált tartós kamrai ritmuszavar miatt vizsgáltunk. A többi esetben a leggyakoribb panasz a palpitáció, effort dyspnoe, presyncope/syncope volt, illetve EKG-eltérések (leggyakrabban összetartozó elvezetésekben ST-, T-eltérések), pozitív kardiovaszkuláris családi anamnézis, vagy echokardiográfia során felmerülő eltérés alapján kérték a szív MR-vizsgálatukat.

A mágneses rezonanciás vizsgálatok elvégzésére 1,5 Tesla térerejü Philips Achieva berendezés szolgált. Transzverzális szeletsorozatban, majd hossztengelyi síkokban mozgó bSSFP (balanced steady-state free precession) felvételeket készítettünk. A bal kamra csúcsa és a mitralis anulus között rövidtengelyi síkokban $8 \mathrm{~mm}$-es szeletvastagsággal cine bSSFP mozgófelvételeket készítettünk, amelynek segítségével meghatároztuk a bal és jobb kamrai ejekciós frakciókat, volumeneket, izomtömeget. További síkokat fektettünk a bal, illetve jobb kamrai kiáramlási pályára az esetleges falmozgászavarok pontosabb megítélésére. Akut eltérés gyanúja esetén T2-súlyozott zsírelnyomásos felvételeket készítettünk a miokardiális ödéma azonosítására. Az esetek 88\%-ában MR-kontrasztanyag adásával egészítettük ki a vizsgálatot, first pass perfúziós felvételeket követően 10-15 perc elteltével késői típusú kontrasztanyag-halmozásos felvételeket készítettünk a miokardiális nekrózis/fibrózis azonosítására.

Vizsgáltuk a klinikai paramétereket, a 12-elvezetéses nyugalmi EKG-felvételt, valamint célzott sportolói kérdőívet vettünk fel, amelynek része volt többek között a személyes és családi anamnézis, és a sporttevékenység időtartamának, intenzitásának felmérése. Kérdéses esetekben a sportolókat dekondicionáltuk, a sporttevékenység időszakos (68-12 hét) felfüggesztését követően ismételt kardiológiai kivizsgálást és kontroll szív MR-vizsgálatot végeztünk.

\section{Eredmények}

A szív MR-vizsgálat a sportolók 25,5\%-ában, 37 férfi és 2 nő sportolónál (átlagéletkor: $27,2 \pm 17,0$ év; 5 esetben 18 év alatti sportoló, illetve 9 master sportoló) igazolt strukturális szívizombetegséget (1. ábra). Az érintettek legnagyobb esetszámban vízilabdázók $(n=5)$, triatlonisták $(n=5)$, labdarúgók $(n=5)$ voltak, kisebb esetszámú sportágak között volt még a maraton, kerékpár, kosárlabda, jégkorong, úszás, kézilabda, küzdősport, diszkoszvetés és öttusa. Azokban az esetekben, ahol az MR-kép, a klinikai paraméterek, illetve dekondicionálás alapján továbbra sem volt egyértelmű a diagnózis, rendszeres kardiológiai utánkövetést (egyéni elbírálás alapján, leggyakrabban: fizikális vizsgálat, 12 elvezetéses nyugalmi EKG, Holter EKG, spiroergometria, echokardiográfia, CMR) javasoltunk, ezen eseteket (15 fő) jelen vizsgálatból kizártuk.

Hipertrófiás cardiomyopathiát 9 esetben ( 7 férfi, átlagéletkor: 18,5 \pm ,8 év), a strukturális szívizombetegségek mintegy 23,0\%-ában azonosítottunk. Típusos, septalis túlsúlyú aszimmetrikus balkamra-hipertrófiát három esetben, koncentrikus balkamra-hipertrófiát két esetben igazoltunk, míg négy sportolónál az MR-kép csúcsi HCM-re volt típusos (2. ábra). A HCM-es csoport átlagos balkamra-izomtömeg indexe (LVMi) 95,4 416,3 $\mathrm{g} / \mathrm{m}^{2}$, a maximális bal kamrai végdiasztolés falvastagság (maxEDWT) átlaga 16,5 $\pm 3,9 \mathrm{~mm}$ volt. A sportszív és HCM elkülönítését segítő hányados: a maxEDWT és bal kamrai végdiasztolés volumen index (LVEDVi) arány 9-ből 8 esetben volt kóros tartományban (maxEDWT/LVEDVi>0,15). A maradék egy esetben, ahol a kritérium nem teljesült, csúcsi hipertrófia és fibrotikus elfajulás alapján állítottuk fel a diagnózist. A hipertrófiás szegmentumokban 7 esetben azonosítottunk fibrotikus elfajulást jelző késői kontrasztanyag-halmozást. Két

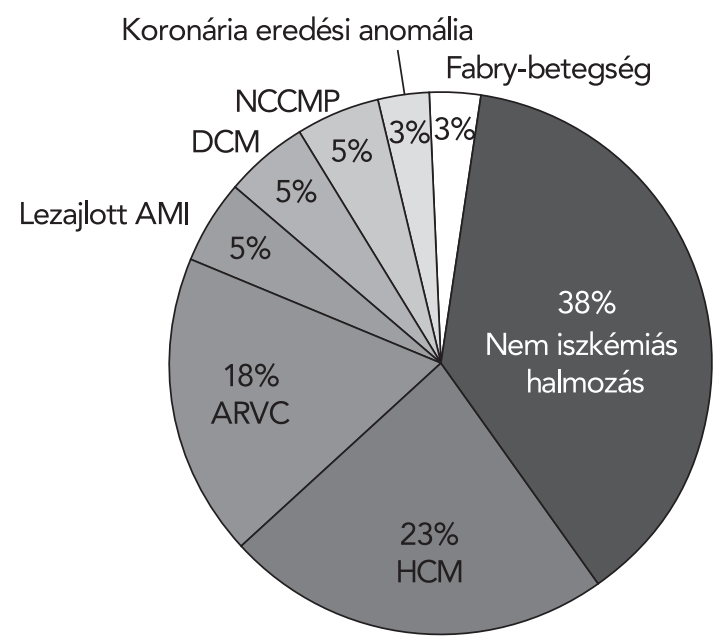

1. ÁBRA. A Városmajori Szív- és Érgyógyászati Klinikán 2011 január és 2016 december között szív MR-rel vizsgált sportolók strukturális szívizombetegségeinek megoszlása 


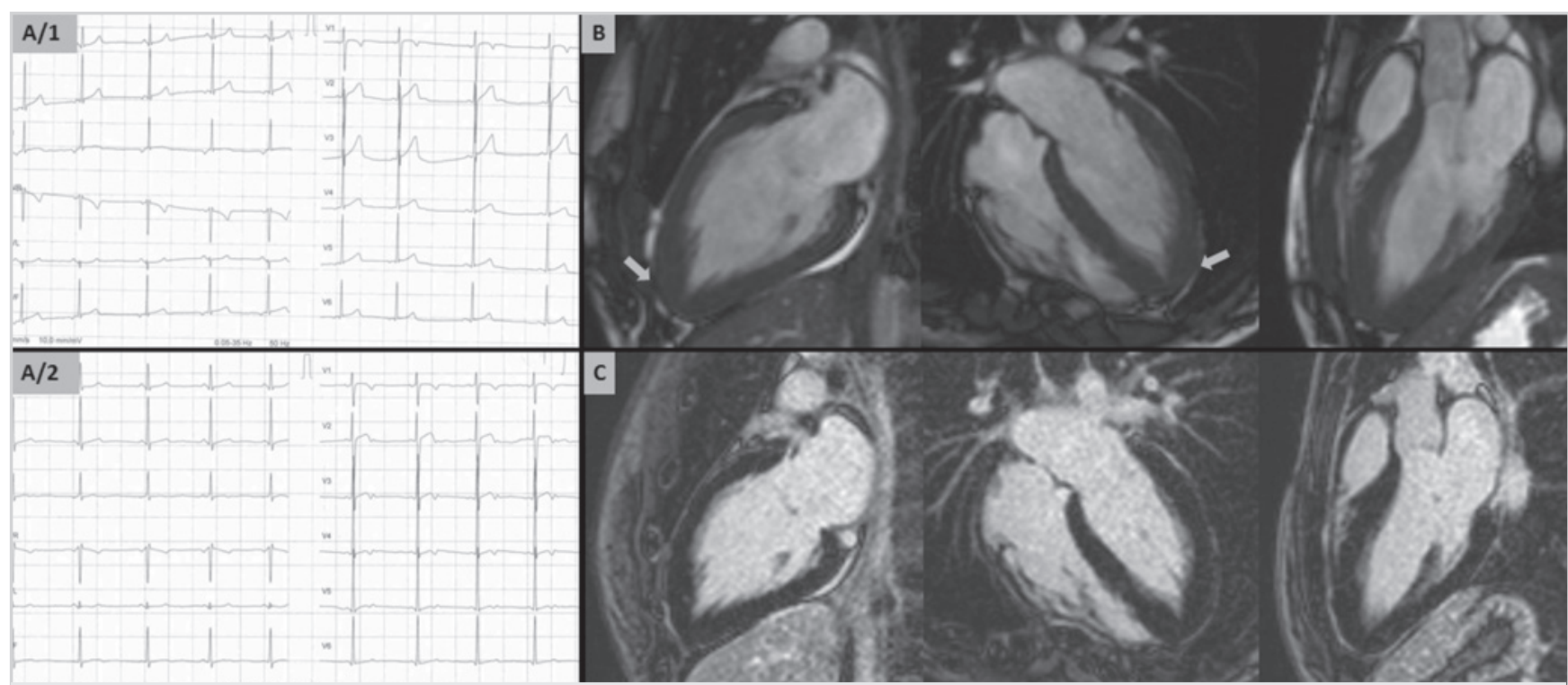

2. ÁBRA. Fiatal öttusázó lány 12-elvezetéses EKG felvételei, valamint szív MR felvételei. A 3 évvel későbbi EKG felvételen ( $A / 2$ ) látható $V_{3}-V_{4}$-elvezetésben megjelenő bifázisos T-hullám. A hossztengelyi szív MR felvételeken (B:bSSFP) látható a csúcsi balkamra-hipertrófia, kötőszövetes elfajulás MR jelei nélkül (C)

esetben a HCM diagnózisának felállításához dekondicionálás is szükséges volt.

Arrhythmogen jobb kamrai cardiomyopathia (ARVC) a vizsgált csoport 18,0\%-ában, 7 esetben (6 férfi, átlagéletkor: $28 \pm 1,4$ év) igazolódott, ebből kétkamrás érintettség három esetben fordult elő (3. ábra). Három sportolónál reanimációt, két esetben dokumentált tartós kamrai tachycardiát követően, két esetben terhelés alatt fellépő presyncope/syncope miatt végeztük a vizsgálatot. Az ARVC diagnózisának felállítását a jobb kamrai falmozgászavar (akinesis, dyskinesis, vagy dyssynchronia), a csökkent jobb kamrai ejekciós frakció, fibrózis jelenléte, valamint az egyéb (legtöbb esetben repolarizációs eltérések) Task Force kritériumokra alapoztuk. A diagnózist három esetben dekondicionálás segítette.

A nonkompakt cardiomyopathia (NCCMP) diagnosztikus kritériumát elérő fokozott bal kamrai trabekularizáció két férfisportoló esetén (5,0\%) igazolódott (4. ábra). Ezekben az esetekben jó, illetve megtartott bal kamrai ejekciós frakciót mértünk (LVEF: $60 \%$ és $50 \%$ ), a bal kamrai volumenek a sportolói normáltartományban voltak (LVEDVi: $127 \mathrm{ml} / \mathrm{m}^{2}$ és $124 \mathrm{ml} / \mathrm{m}^{2}$ ).

További két esetben $(5,0 \%)$ a kontraszthalmozási mintázat, a bal kamrai tágulat, illetve az enyhén csökkent bal kamrai ejekciós frakció dilatatív cardiomyopathia (DCM) MR-képének felelt meg (LVEF: $49 \%$ és $47 \%$, LVEDVi: $131 \mathrm{ml} / \mathrm{m}^{2}$ és $\left.153 \mathrm{ml} / \mathrm{m}^{2}\right)$.

Két férfi maratonfutónál (39 és 50 év) szubendokardiális, korábbi miokardiális infarktus maradványhegét jelző késői kontrasztanyag-halmozás ábrázolódott (5. ábra). A sportolók kardiálisan panaszmentesek voltak, szürővizsgálat során felfedezett EKG-eltérések miatt kerültek részletes kardiológiai kivizsgálásra. A koro-

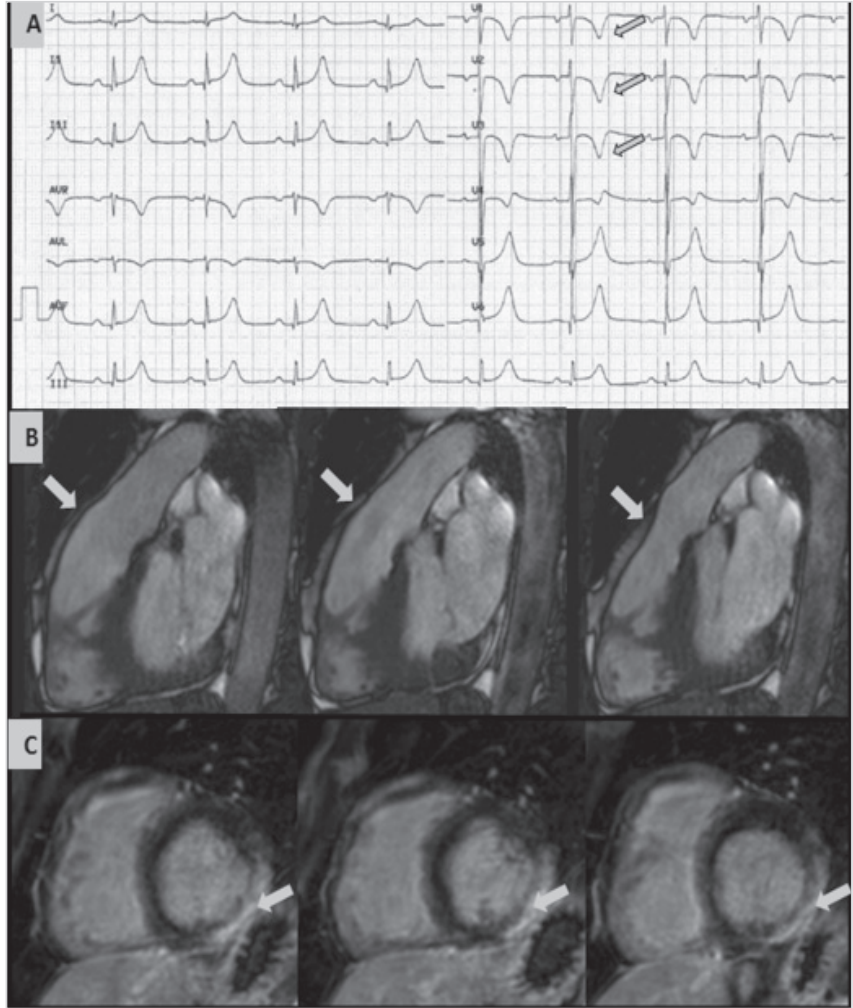

3. ÁBRA. ARVC-s kerékpáros élsportoló 12 elvezetéses EKG és szív MR felvétele. Az EKG felvételen (A) látható $V_{1-3}$ elvezetésekben negatív, $\mathrm{V}_{4}$ elvezetésben bifázisos T-hullám. A jobb kamrai kiáramlási traktusra fektetett síkokban készült bSSFP felvételeken pontosan megítélhető a jobb kamrai dyskinesis (B). A rövidtengelyi síkokban készült késői típusú kontraszthalmozásos felvételeken látható a bal kamra basalis inferolateralis szegmentumának subepicardialis fibrotikus elfajulása (C) 


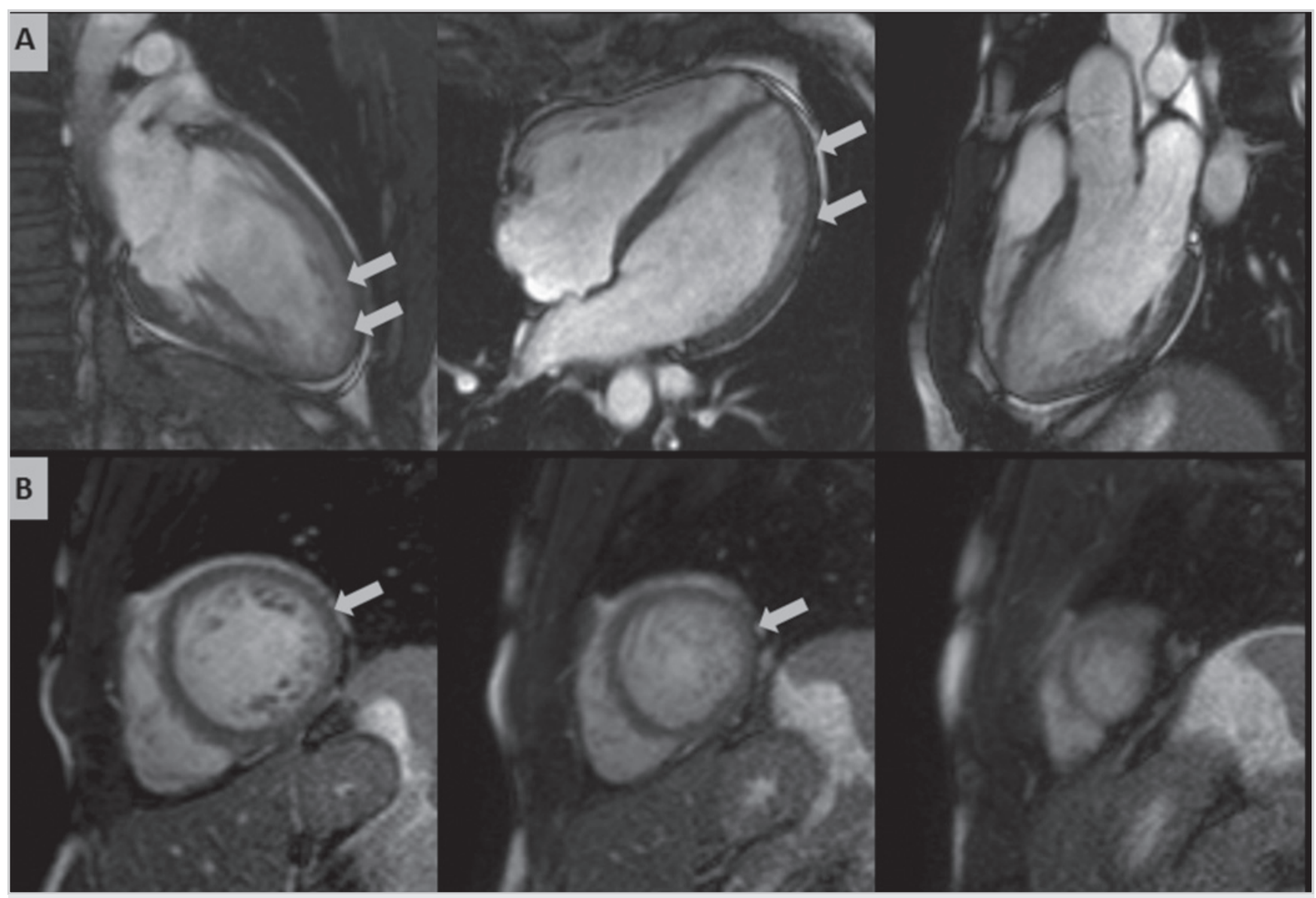

4. ÁBRA. Nonkompakt CMP diagnosztikus kritériumának teljesülése fiatal sportolónál. A hossz- (A) és rövidtengelyi (B) bSSFP felvételeken a lateralis, valamint a csúcsi kifejezett trabecularisatio ábrázolódik

náriabetegség tényét ennél a két betegnél az invazív koronarográfia igazolta. Az anatómia és a funkció kapcsolatának fontosságát jelzi, hogy az egyik betegnél a proximális LAD-okklúzió mellett a CX-ágon csak határérték stenosis volt látható, ennek ellenére - vélhetően az extrém terhelés következtében - az MR-vizsgálat ezen a területen is definitív nekrózist mutatott (5. ábra). A koronária eredési anomáliával rendelkező szintén panaszmentes férfi sportolónál minor EKG-eltérés miatt kezdtünk kardiológiai kivizsgálást. A jobb koronáriás tasakból aberráns eredést mutató, interarterialis lefutású bal fötörzs volt azonosítható.

Egy muay thai küzdősportot üző férfinél echokardiográfia során leírt $19 \mathrm{~mm}$-es laterális falvastagság miatt végeztünk szív MR-vizsgálatot. Az MR-en látott kifejezett balkamra-hipertrófia és a basalis inferolateralis szegmentumban ábrázolódó mid-miokardiális késői kontraszthalmozás Anderson-Fabry-betegség erős gyanúját vetette fel, amelyet a további részletes kivizsgálás igazolt (5. ábra).

Tizenöt esetben noniszkémiás eredetre utaló késői típusú kontraszthalmozás ábrázolódott. Közülük öszszesen három sportolónál láttunk falmozgászavart, a maradék 12 esetben jó bal kamrai ejekciós frakciót mértünk, falmozgászavar nélkül. EKG-eltérés mind-
Össze 7 esetben volt megfigyelhető. Nyolc esetben gócos, subepi-midmiokardiális jellegű kontraszthalmozási mintázat igazolódott, amely leginkább lezajlott myocarditis maradványhegének felelhet meg, közülük három sportolónál volt ismert lezajlott myocarditis. A noniszkémiás kontraszthalmozási mintázatot mutató sportolók közül 7 esetben atípusos halmozási mintázat volt jelen (5. ábra).

Azon sportolóknál, akiknél abortált hirtelen szívhalált követően végeztük az MR-vizsgálatot, öt esetben találtunk strukturális eltérést, a korábban említett három ARVC-s sportolón kívül a másik két sportoló az atípusos kontraszthalmozó csoportba tartozott. A reanimált betegek további kivizsgálása során két sportolónál hosszú QT-szindróma, egy esetben Brugada-szindróma, illetve szintén egy esetben WPW-szindróma volt azonosítható. A dokumentált tartós VT miatt vizsgált két férfi kerékpáros versenysportolónál ARVC igazolódott.

\section{Megbeszélés}

A sportszív különböző strukturális szívizombetegségektől való elkülönítése gyakran kihívást jelent a mindennapi gyakorlatban. 

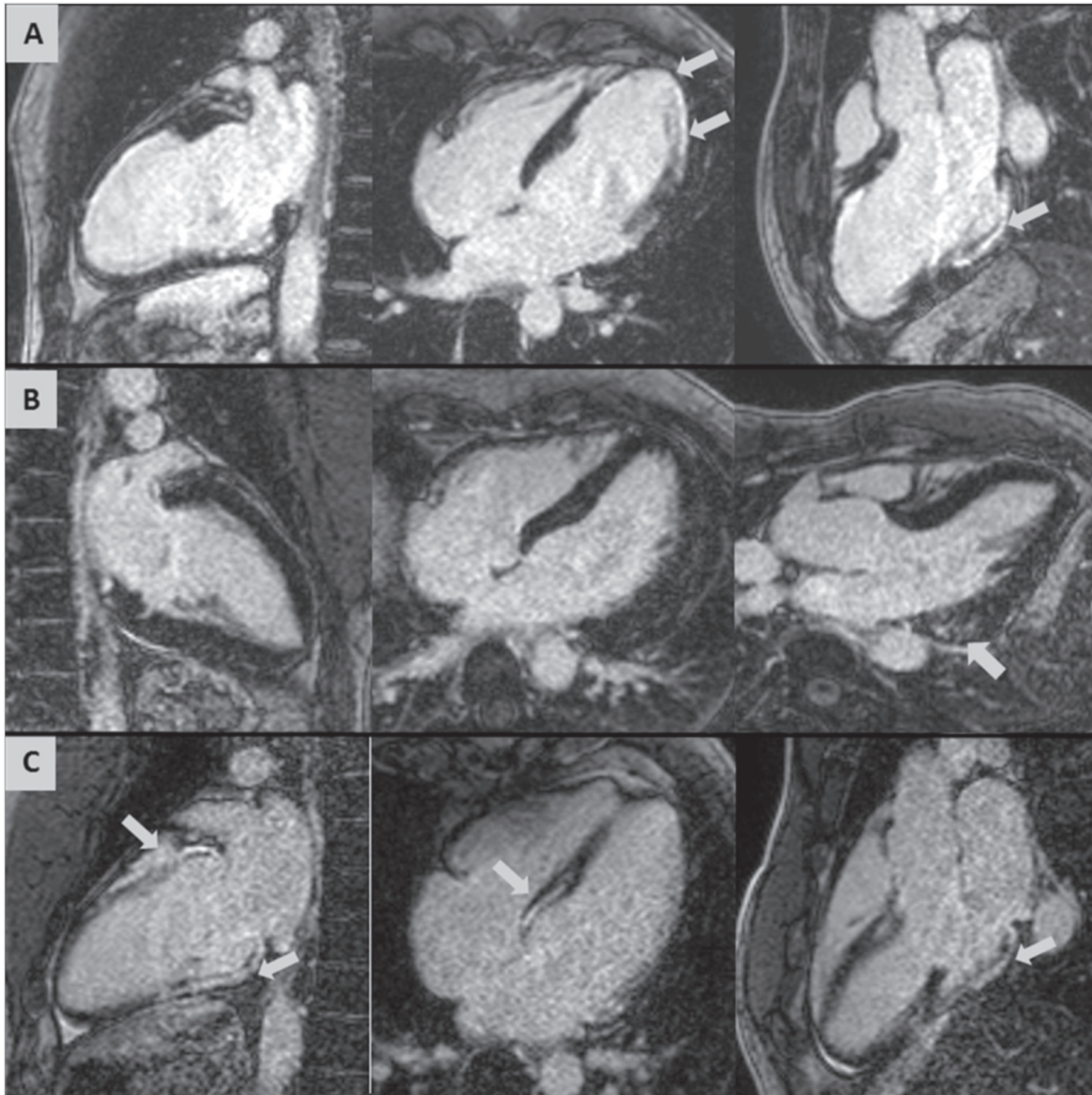

5. ÁBRA. Hosssztengelyi késői kontraszthalmozásos szív MR felvételek. Lezajlott miokardiális infarktus MR jelei panaszmentes maratonfutónál. Az MR felvételeken kettős lokalizációjú, középső és csúcsi harmadbeli anterior, anteroseptalis és csúcsot érintő, illetve basalis inferior és inferolateralis subendocardialis késői kontraszthalmozás (LGE) ábrázolódik (A). Fabry-betegségre típusos basalis inferolateralis szegmentumra lokalizált midmyocardialis fibrózis (B), kiterjedt atípusos fibrózis MR jelei egy korábban doppingvétség miatt eltiltott élsportolónál (C)

A HCM-ben kialakult kóros balkamra-hipertrófia sportszívtöl való elkülönítése sok esetben nehezített. Az EKG-n és a részletes anamnézisen túl a differenciáldiagnosztikát segítheti az echokardiográfia során mért sportolókra jellemző $55 \mathrm{~mm}$ feletti bal kamra átmérő, illetve a HCM gyanúját erősítő $15 \mathrm{~mm}$ feletti maximális végdiasztolés falvastagság, az aszimmetrikus balkamra-hipertrófia és diasztolés diszfunkció $(1,12,14,15)$. Szív MR-vizsgálattal az echokardiográfiával nehezen megítélhető szegmentumok (pl. csúcs) is kiválóan értékelhetőek, továbbá kimutatható az esetleges kötőszövetes elfajulás. A 0,15 feletti maximális végdiasztolés falvastagság/végdiasztolés volumen index arány szintén segíthet a HCM és sportszív elkülönítésében (11, 16). Az idiopátiás balkamra-hipertrófiás esetek hátterében állhat metabolikus ok is, leggyakrabban AndersonFabry-kór, amely egy lizoszomális tárolási betegség. Az a-galaktozidáz-A enzim hiánya vagy csökkent mü- 
ködése miatt lipid lebontási termékek halmozódnak fel a szívizomban. A kórkép MR megjelenésére a balkamra-hipertrófia mellett típusos a basalis inferolateralis szegmentumot érintő midmiokardiális késői kontrasztanyag-halmozás (17). Amennyiben az MR-vizsgálat felveti a betegség gyanúját, a diagnózis enzimszintmérés, illetve genetikai vizsgálat segítségével igazolható (17, 18).

Az ARVC diagnosztikájának alapját képező, jelenleg érvényben lévő Task Force ajánlás nem tartalmaz sportolók esetén alkalmazható kritériumokat annak ellenére, hogy a jobb kamrai végdiasztolés volumen index egészséges versenysportolókban is eléri a major kritérium értékét $(11,19)$. A diagnosztikát esetükben a jobb kamrai ejekciós frakció, illetve a bal és jobb kamrai ejekciós frakciók, valamint végdiasztolés volumenek aránya segítheti (20). Ezen paraméterek tekintetében nagy esetszámú egészséges élsportolói és ARVC-s betegcsoport alapján meghatározott cut-off értékekre volna szükség.

A sportszív és a korai fázisú DCM elkülönítése a mindkettőre jellemző megnövekedett kamrai és pitvari volumenek miatt szintén nehezített lehet $(6,21)$. A rutinszerüen alkalmazott diagnosztikus eljárások mellett kérdéses esetekben a szív MR-vizsgálat pontos funkcionális ismereteket nyújtva, valamint a DCM-ben esetlegesen jelen lévő midmiokardiális késői kontraszthalmozási mintázat azonosításával segíthet.

A differenciáldiagnosztikát a fenti kórképek esetén a sportolók dekondicionálása is segítheti. Már rövidtávú, 1-3 hónapos dekondicionálás hatására fiziológiás esetben kifejezett reverz remodelling figyelhető meg mind a kamravolumenek, mind az izomtömegek tekintetében, míg patológiás állapotokban részleges reverz remodellinget látunk, az adott paraméterek kóros tartományban maradnak $(6,22,23)$. A genetikai öröklődésű kórképek esetén az elvégzett genetikai teszt is hozzájárulhat a diagnózis felállításához.

NCCMP esetén egyre több adat utal arra, hogy az eltérés nem külön entitás, hanem specifikus morfológiai jegy, amely társulhat dilatatív, hipertrófiás és restriktív szívizombetegséggel is, továbbá a bal kamrai trabekularizáció egészséges sportolók mintegy $8 \%$-ában eléri a jelenleg kórosnak tartott mértéket (trabekularizált/ kompakt szívizom aránya>2,3 (24). Ezen sportolóknál a normál szisztolés funkció, a patológiás EKG-jelek és komplex kamrai aritmia hiánya, illetve a negatív családi anamnézis jó prognózisra utal (6).

Iszkémiás szívbetegség főként a 35 év feletti sportolók esetén fordul elő $(1,5,6)$. A szív MR-vizsgálatnak fontos szerepe lehet a noniszkémiás és az iszkémiás eredetű szívizom-károsodások elkülönítésében (miokardiális infarktus esetén az érintett koronária ellátási területén szubendokardiális/transmuralis késői típusú kontraszthalmozás). Az MR-vizsgálat alkalmas a koronária eredési, illetve lefutási anomáliák azonosítására is.
Irodalmi adatok alapján akut myocarditis szintén gyakran áll a sportolói HSZH-esetek hátterében. Intenzív fizikai terhelés az akut myocarditis progresszióját okozza, akut myocarditis a versenysporttól való ideiglenes eltiltás egyértelmű indikációja $(11,25)$. A szív MR-rel azonosítható lezajlott myocarditist követően fennmaradt hegek szerepéröl sportolók esetén nem rendelkezünk kellő irodalmi adattal.

Magyarországon ez az első, sportolók körében végzett, szív MR-diagnosztikát alkalmazó strukturális szívizombetegség gyakoriságát célzó tanulmány. A cardiomyopathiák közül az általunk vizsgált csoportban a leggyakoribb kórkép a HCM, míg a hirtelen szívhalál hátterében álló leggyakoribb strukturális eltérés az ARVC volt. A szív MR-vizsgálat atípusos miokardiális fibrózist falmozgászavar, illetve EKG-eltérés hiányában is igazolhat, ám a háttérben álló kórkép az esetek egy részében részletes kivizsgálást követően sem azonosítható egyértelmúen. Az ajánlásokon alapuló, egyénre szabott rizikóstratifikáció segíthet a veszélyeztetett sportolók kiszűrésében, a HSZH megelőzésében, emellett a versenysporttól történő felesleges eltiltások gyakoriságának csökkentésében is. A noninvazív képalkotó technikák, mint a szív MR-technika fejlődése révén a jövőben nemcsak a diagnózis felállításában, hanem a rizikóstratifikációban is meghatározó szerepet tölthetnek be.

\section{Köszönetnyilvánítás \\ A kutatást támogatta a Nemzeti Kutatási, Fejlesztési és Innovációs Hivatal - NKFIH (K 120277). Köszönettel tartozunk továbbá a Klinika CMR és a sportolók vizsgá- lataiban részt vevő valamennyi asszisztensének lelkiis- meretes munkájáért.}

\section{Irodalom}

1. Harmon KG, Drezner JA, Wilson MG, Sharma S. Incidence of sudden cardiac death in athletes: a state of the art review. Heart 2014; 100: 1227-34

https://doi.org/10.1136/heartjnl-2014-093872.rep

2. Corrado D, Pelliccia A, Bjørnstad HH, et al. Cardiovascular preparticipation screening of young competitive athletes for prevention of sudden death: proposal for a common European protocol. European Heart Journal 2005; 26(5): 516-524.

https://doi.org/10.1093/eurheartj/ehi108

3. Priori SG, Blomström-Lundqvist C, Mazzanti A. et al. ESC Guidelines for the management of patients with ventricular arrhythmias and the prevention of sudden cardiac death. European Heart Journal 2015. https://doi.org/10.1093/eurheartj/ehi108

4. Maron BJ, Doerer JJ, Haas TS, Tierney DM, Mueller FO. Sudden deaths in young competitive athletes: analysis of 1866 deaths in the United States, 1980-2006. Circulation 2009; 119: 1085-92.

https://doi.org/10.1161/CIRCULATIONAHA.108.804617

5. Maron BJ, Haas TS, Murphy CJ, Ahluwalia A, Rutten-Ramos S. Incidence and causes of sudden death in U.S. college athletes. J Am Coll Cardiol 2014; 63: 1636-43.

https://doi.org/10.1016/j.jacc.2014.01.041

6. Mont L, Pelliccia A, Sharma S, et al. Pre-participation cardiovascular evaluation for athletic participants to prevent sudden death: Position paper from the EHRA and the EACPR, branches of the 
ESC. Endorsed by APHRS, HRS, and SOLAECE. Europace 2016. https://doi.org/10.1177/2047487316676042

7. Corrado D, Basso C, Rizzoli G, Schiavon M, Thiene G. Does sports activity enhance the risk of sudden death in adolescents and young adults? J Am Coll Cardiol 2003; 42: 1959-63.

https://doi.org/10.1016/j.jacc.2003.03.002

8. Corrado D, Thiene G, Nava A, Rossi L, Pennelli N. Sudden death in young competitive athletes: clinicopathologic correlations in 22 cases. Am J Med 1990; 89: 588-96.

https://doi.org/10.1016/0002-9343(90)90176-目

9. Semsarian C, Ingles J, Maron MS, Maron BJ. New perspectives on the prevalence of hypertrophic cardiomyopathy. J Am Coll Cardiol 2015; 65: 1249-54. https://doi.org/10.1016/j.jacc.2015.01.019 10. Maron BJ, Niimura H, Casey SA, Soper MK, Wright GB, Seidman JG et al. Development of left ventricular hypertrophy in adults in hypertrophic cardiomyopathy caused by cardiac myosin-binding protein C gene mutations. J Am Coll Cardiol 2001; 38: 315-21. https://doi.org/10.1016/S0735-1097(01)01386-9

11. Maron BJ, Udelson JE, Bonow RO, et al. Eligibility and Disqualification Recommendations for Competitive Athletes With Cardiovascular Abnormalities: Task Force 3: Hypertrophic Cardiomyopathy, Arrhythmogenic Right Ventricular Cardiomyopathy and Other Cardiomyopathies, and Myocarditis: A Scientific Statement From the American Heart Association and American College of Cardiology. Circulation 2015. https://doi.org/10.1161/CIR.0000000000000239

12. Sharma S, Maron BJ, McKenna WJ, et al. Physiologic limits of left ventricular hypertrophy in elite junior athletes: relevance to differential diagnosis of athlete's heart and hypertrophic cardiomyopathy. Journal of the American College of Cardiology 2002; 40: 1431-6. https://doi.org/10.1016/S0735-1097(02)02270-2

13. Sportegészségügyi Szakmai Kollégium. Az Egészségügyi Minisztérium módszertani levele: Sportolás közben fellépő hirtelen szívhalál megelőzésének lehetősége Egészségügyi Közlöny 2005. 14. Prakken $\mathrm{NH}$, Velthuis BK, Cramer MJ, et al. Advances in cardiac imaging: the role of magnetic resonance imaging and computed tomography in identifying athletes at risk. British Journal of Sports Medicine 2009; 43: 677-684. https://doi.org/10.1136/bjsm.2008.054767 15. Vágó $H$, Tóth $A$, Merkely $B$, et al. Differentiation of physiological sport adaptation from pathological left ventricular hypertrophy with the help of trabeculae quantification using cardiac magnetic resonance imaging, European Society of Cardiology Congress 2015.
16. Petersen S, Selvanayagam JB, Francis JM, et al. Differentiation of athlete's heart from pathological forms of cardiac hypertrophy by means of geometric indices derived from cardiovascular magnetic resonance Journal of Cardiovascular Magnetic Resonance 2005; 7 : 551-558. https://doi.org/10.1081/JCMR-200060631

17. Elliott PM, Anastasakis A, Borger MA, et al. ESC Guidelines on diagnosis and management of hypertrophic cardiomyopathy: web addenda The Task Force for the Diagnosis and Management of Hypertrophic Cardiomyopathy of the European Society of Cardiology (ESC). European Heart Journal 2014.

https://doi.org/10.1093/eurheartj/ehu284

18. Constantin T, Fekete Gy, et al. Fabry-betegség. Orvosi Hetilap 2010; 151(31): 1243-1251. https://doi.org/10.1556/OH.2010.28796

19. Marcus IF, McKenna WJ, Sherrill D, et al. Diagnosis of Arrhythmogenic Right Ventricular Cardiomyopathy/Dysplasia Proposed Modification of the Task Force Criteria. Circulation 2010; 121: 1533-1541. https://doi.org/10.1161/CIRCULATIONAHA.108.840827

20. Czimbalmos Cs, Vágó $H$, Merkely B, et al. Differentiation of arrhythmogenic right ventricular cardiomyopathy and athlete's heart using cardiac magnetic resonance imaging. European Society of Cardiology Congress 2015.

21. Pelliccia A, Culasso F, Di Paolo FM, Maron BJ. Physiologic left ventricular cavity dilatation in elite athletes. Ann Intern Med 1999 Jan 5; 130(1): 23-31.

https://doi.org/10.7326/0003-4819-130-1-199901050-00005

22. Ehsani AA, Hagberg JM, Hickson RC. Rapid changes in left ventricular dimensions and mass in response to physical conditioning and deconditioning. Am J Cardiol 1978; 56(42): 52-56.

https://doi.org/10.1016/0002-9149(78)90984-0

23. Biffi A, Maron BJ, Culasso F. Patterns of ventricular tachyarrhythmias associated with training, deconditioning and retraining in elite athletes without cardiovascular abnormalities. American Journal of Cardiology 2011; 031107(5): 697-703.

https://doi.org/10.1016/j.amjcard.2010.10.049

24. Petersen SE, Selvanayagam JB, Wiesmann F, et al. Left ventricular non-compaction: insights from cardiovascular magnetic resonance imaging. Journal of the American Collage of Cardiology 2005; 46: 101-105. https://doi.org/10.1016/j.jacc.2005.03.045

25. Sportegészségügyi Szakmai Kollégium. Az Egészségügyi Minisztérium szakmai protokollja a sportorvosi alkalmassági- és szűrővizsgálatokról. Egészségügyi Közlöny 2008. 